\title{
PENGARUH TINGKAT INVESTASI DAN ANGKATAN KERJA TERHADAP PERTUMBUHAN EKONOMI DI INDONESIA
}

\author{
Mario Nicolas Munthe \\ Staff BPS Papua Barat Jl. Trikora Sowi IV No. 99, Manokwari - Papua Barat 98315 Indonesia, \\ Email: mario.munthe@bps.go.id
}

\begin{abstract}
This study aims to determine the effect of investment and labor force on economic growth in Indonesia. The population in this study were all provinces in Indonesia as many as 33 provinces as well as being sampled with the 2011-20014 study period. The analytical model used is multiple linear regression with panel data and fixed effects models, but first performed a classic assumption test. The results of the study show that the level of investment and labor force partially have a positive and significant influence on economic growth. The most dominant variable affecting economic growth in Indonesia is employment
\end{abstract}

Keywords: Economic growth, investment and labor force

\section{PENDAHULUAN}

Pembangunan merupakan suatu usaha atau rangkaian usaha pertumbuhan dan perubahan yang berencana dan dilakukan secara sadar oleh suatu bangsa, negara, dan pemerintah, menuju modernitas dalam rangka pembinaan bangsa, yang mencakup seluruh sistem sosial, politik, ekonomi, infrastruktur, pertahanan, pendidikan dan teknologi, kelembagaan, dan budaya. Pembangunan juga meliputi perubahan dalam tingkat pertumbuhan ekonomi, pengurangan ketimpangan pendapatan, dan pemberantasan kemiskinan. Untuk mencapai sasaran yang diinginkan, maka pembangunan suatu negara dapat diarahkan pada tiga hal pokok utama yaitu, meningkatkan ketersediaan dan distribusi kebutuhan pokok bagi masyarakat, meningkatkan standar hidup masyarakat dan meningkatkan kemampuan masyarakat dalam mengakses baik kegiatan ekonomi maupun kegiatan sosial dalam kehidupan (Todaro, 2009).

Salah satu indikator untuk mengukur keberhasilan pembangunan suatu wilayah atau daerah adalah peningkatan pertumbuhan ekonomi. Pertumbuhan ekonomi dapat diartikan sebagai kegiatan dalam perekonomian yang menyebabkan barang dan jasa yang diproduksi dalam masyarakat bertambah sehingga akan meningkatkan kemakmuran masyarakat (Sukirno, 1994). Menurut Soeharno (2007), pertumbuhan ekonomi adalah kenaikan jangka panjang kemampuan suatu negara untuk menyediakan semakin banyak jenis barang-barang ekonomi bagi para penduduknya. Salah satu indikator penting untuk mengetahui kondisi perekonomian di suatu wilayah dalam suatu periode tertentu ditunjukkan oleh perkembangan Produk Domestik Bruto (PDB), baik atas dasar harga berlaku atau atas dasar harga konstan.

Perkembangan Produk Domestik Bruto Indonesia dari tahun 2000 hingga tahun 2014 selalu mengalami peningkatan setiap tahunnya. Produk Domestik Bruto Indonesia pada tahun 2014 sudah mencapai 2,9 triliun rupiah atau hampir dua kali lipat dibandingkan PDB Indonesia pada tahun 2000. Laju pertumbuhan PDB Indonesia tahun 2000 hingga tahun 2014 secara rata-rata bertumbuh 5,4 persen setiap tahunnya. Dapat dikatakan pertumbuhan ekonomi Indonesia tumbuh dengan lumayan pesat. Namun, pada tahun 2011 hingga tahun 2014 Indonesia mengalami perlambatan laju pertumbuhan hingga turun menjadi sebesar 0,67 persen di tahun 2014 dan Indonesia juga masih termasuk dalam negara lower middle income atau negara berpendapatan menengah kebawah menurut Bank Dunia. Oleh karena itu, pemerintah Indonesia seharusnya lebih meningkatkan kembali pertumbuhan ekonomi di 
Indonesia agar pembangunan dapat berjalan dengan baik. Adapun pertumbuhan ekonomi periode tahun 2001-2014 disajikan pada gambar 1 berikut.

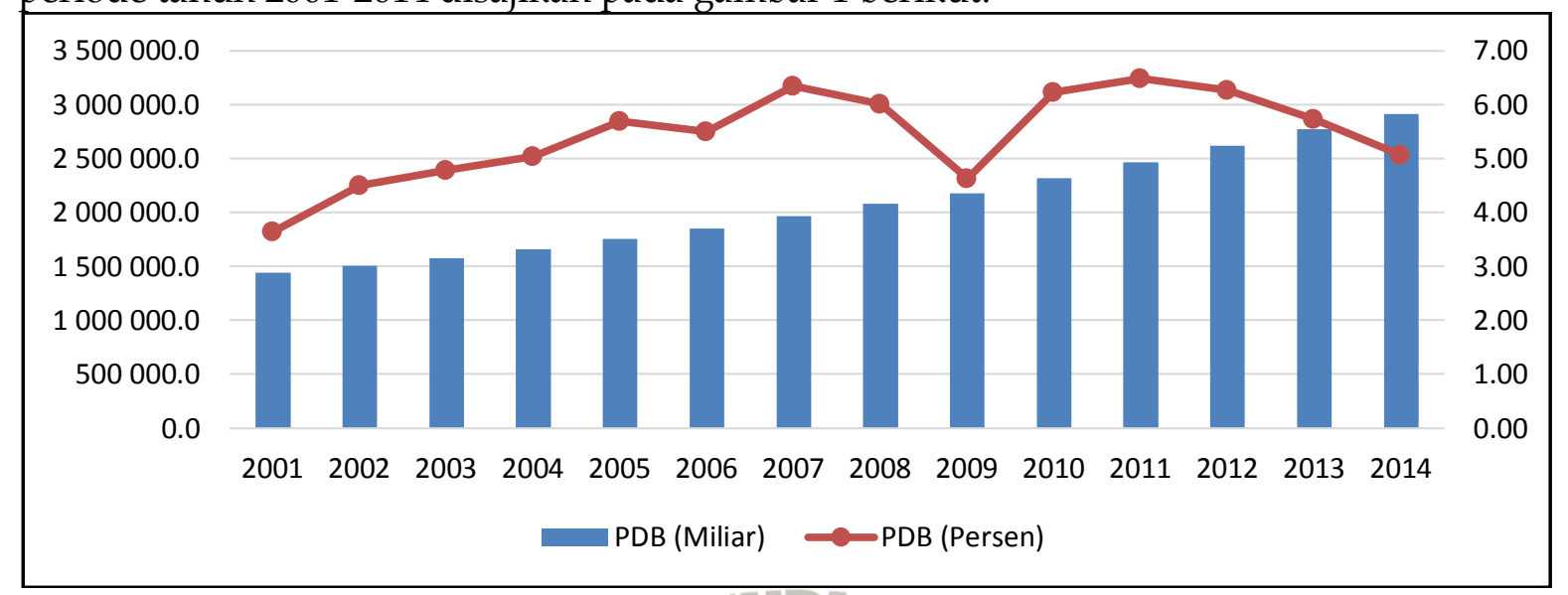

Gambar 1. Perkembangan Produk Domestik Bruto Indonesia tahun 2000-2014 Sumber: Badan Pusat Statistik, diolah

Pertumbuhan ekonomi dapat ditingkatkan dengan melakukan berbagai upaya. Salah satu upaya yang dapat dilakukan adalah dengan meningkatkan arus investasi atau penanaman modal masuk ke Indonesia, baik penanaman modal dari dalam negeri maupun dari asing atau luar negeri. Hal ini sesuai dengan apa yang dikemukan oleh Sukirno (2000) yang menyatakan bahwa kegiatan investasi yang dilakukan oleh masyarakat secara terus menerus akan meningkatkan kegiatan ekonomi dan kesempatan kerja, meningkatkan pendapatan nasional dan meningkatkan taraf kemakmuran masyarakat. Peranan ini bersumber dari tiga fungsi penting dari kegiatan investasi, yakni: (1) investasi merupakan salah satu komponen dari pengeluaran agregat, sehingga kenaikan investasi akan meningkatkan permintaan agregat, pendapatan nasional serta kesempatan kerja, (2) pertambahan barang modal sebagai akibat investasi akan menambah kapasitas produksi dan (3) investasi selalu diikuti oleh perkembangan teknologi. Melalui kegiatan investasi ini juga dapat menciptakan lapangan pekerjaan sehingga jumlah tenaga kerja semakin banyak dan dapat meningkatkan pertumbuhan ekonomi.

Selain menambah investasi dan tenaga kerja melalui penciptaan lapangan pekerjaan, pertumbuhan ekonomi dapat juga ditingkatkan melalui peningkatan produktivitas. Produktivitas merupakan kunci pendorong vital dalam pertumbuhan ekonomi, yakni sebagai daya ungkit (leverage) bagi pertumbuhan ekonomi nasional dalam jangka panjang. Itulah salah satu alasan mengapa dewasa ini banyak negara yang berlomba dalam meningkatkan produktivitas karena semakin tinggi produktivitas suatu negara maka akan semakin tinggi pula pertumbuhan ekonomi negara itu.

Perkembangan produktivitas tenaga kerja di Indonesia dari tahun 1990 sampai dengan 2013 terlihat meningkat setiap tahunnya dan mengalami produktivitas tertinggi pada tahun 2013 dengan indeks sebesar 1,577. Hal ini menunjukkan terjadi peningkatan yang sangat signifikan dari segi produktivitas Indonesia yang pada tahun 1990 masih pada angka indeks 0,783 dan juga apabila dibandingkan dengan negara tetangga Indonesia seperti Malaysia, Singapura, dan Thailand, Indonesia memiliki indeks produktivitas yang paling tinggi di kawasan Asia Tenggara. Namun,apabila dibandingkan dengan negara-negara seperti India dan Tiongkok, Indonesia masih sangat tertinggal dibanding dua negara tersebut. Adapun Indeks produktivitas tenaga kerja negara kawasan Asia tahun 1990-2013 disajikan pada gambar 2 berikut. 


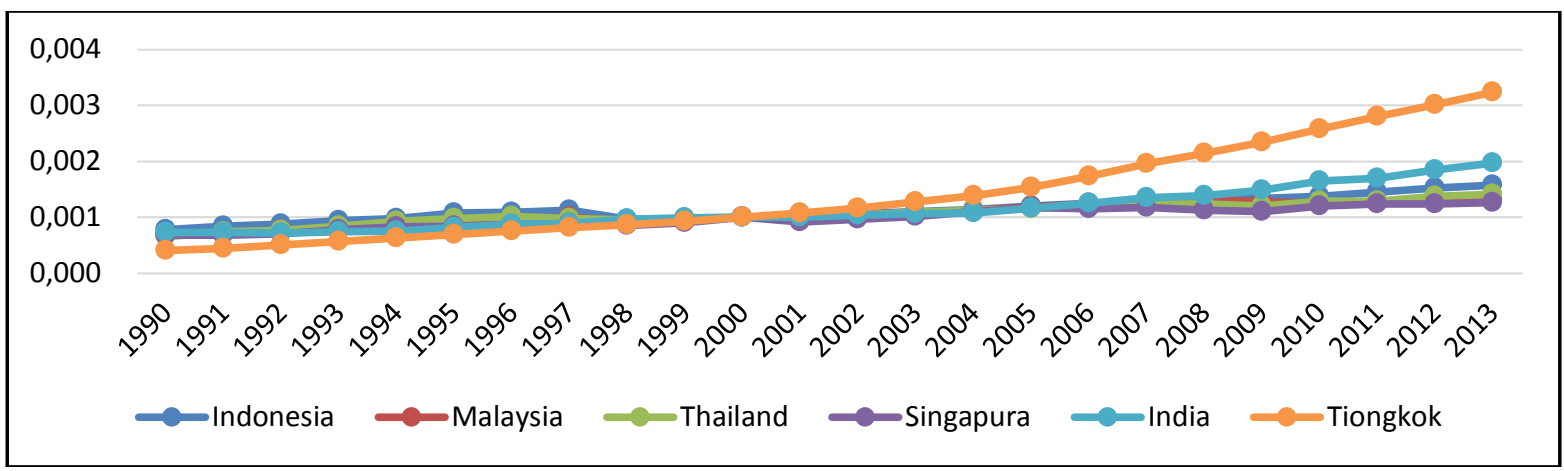

Gambar 2. Indeks produktivitas tenaga kerja negara kawasan Asia tahun 1990-2013 Sumber: Asian Productivity Organization, diolah

Namun, usaha-usaha Indonesia untuk meningkatkan pertumbuhan ekonomi, seperti meningkatkan jumlah tenaga kerja dan modal maupun meningkatkan kualitas modal dan tenaga kerja,mengalami trade off antara pemenuhan kebutuhan pembangunan disatusisi dan upaya mempertahankan kelestarian lingkungan disisi lain.Pembangunan ekonomi yang berbasis sumber daya alam yang tidak memperhatikan aspek kelestarian lingkungan pada akhirnya akan berdampak negatif pada lingkunganitu sendiri, karena pada dasarnya sumber daya alam dan lingkungan memilikikapasitas daya dukung yang terbatas. Dengan kata lain, pembangunan ekonomi yangtidak memperhatikan kapasitas sumber daya alam dan lingkungan akan menyebabkanpermasalahan pembangunan dikemudian hari. Hal ini sesuai dengan yang dikatakan oleh Todaro (2009) bahwa pembangunan ekonomi yang terlalu berorientasi dalam mengejar pertumbuhan ekonomi cenderung mengakibatkan kerusakan lingkungan hidup yang semakin meluas.

Berdasarkan uraian latar belakang di atas maka dirumuskan permasalahan yaitu :

1. Apakah tingkat investasi dan anagkatan kerja berpengaruh positif dan signifikan terhadap pertumbuhan ekonomi?

2. Bagaimana gambaran Total Factor Productivity dan Green Total Factor Productivity Indonesia?

\section{TINJAUAN PUSTAKA}

\section{A. Teori Pertumbuhan Ekonomi}

Pertumbuhan ekonomi menurut Boediono(1992) adalah proses kenaikan output perkapita dalam jangka panjang. Ada tiga aspek yang ditekankan dari pertumbuhan ekonomi, yaitu: proses, output perkapita dan jangka panjang. Pertumbuhan ekonomi adalah suatu "proses", bukan suatu gambaran ekonomi pada suatu saat. Pada aspek ini melihat bagaimana suatu perekonomian berubah dari waktu ke waktu. Aspek kedua yaitu pertumbuhan ekonomi berkaitandengankenaikan" outputperkapita". Teoriiniharusmencangkupteorimengenaipertumb uhanPDBtotaldanpertumbuhanpendudukatautenagakerja.Aspekterakhiryaitudefinisipertumb uhanekonomiadalahperspektifjangkapanjang.Pertumbuhanekonomiterjadiapabilaadakecender ungan(outputperkapitanaik)yangbersumberdariprosesinternalperekonomiantersebut.Prosespe rtumbuhanekonomijugaharusmemilikisifatselfgenerating,yangberartiprosespertumbuhanitusen dirimenghasilkankekuatanatau"momentum" bagikelanjutanpertumbuhantersebutpadaperiode selanjutnya. Penelitian ini lebih banyak berlandaskan pada teori pertumbuhan Neoklasik, yaitu, Teori Robert Solow-Trevor Swan.

\section{B. Teori Pertumbuhan Neoklasik}

Teori pertumbuhan neoklasik dikembangkan oleh Solow (1970) dari MIT dan Swan (1956) dari Australian National University. Model pertumbuhan Solow merupakan pengembangan dari formulasi Harrod-Domar dengan menambahkan factor kedua, yakni 
tenaga kerja. Model Solow ini juga memperkenalkan varia belin dependen ketiga, yakni teknologi kedalam persamaan pertumbuhan (equationgrowth). Kerangka umum model SolowSwan menurut Boediono (1992) meskipun mirip dengan model Harrod-Domar, tetapi model Solow-Swan lebih "luwes" karena: (1) Menghindari masalah "ketidakstabilan" yang merupakan cirri warranted rate of growth dalam model Harrod-Domar, dan (2) Bisa lebih "luwes" digunakan untuk menjelaskan masalah-masalah distribusi pendapatan.

Model Solow-Swan lebih luwes daripada model Harrod-Domar karena menggunakan bentuk fungsi produksi yang lebih mudah "dimanipulasi" secara aljabar. Model SolowSwan memungkinkan adanya substitusi antara input kapital

(K) dan input tenaga kerja (L). Sedangkan model Harrod-Domar, masing-masing input nya dihubungkan oleh fungsi produksi dengan koefisien yang tidak dapat berubah.

\section{Angkatan Kerja dan Pertumbuhan Ekonomi}

Menurut Todaro (2000) pertumbuhan penduduk dan pertumbuhan Angkatan Kerja (AK) secara tradisional dianggap sebagai salah satu faktor positif yang memacu pertumbuhan ekonomi. Jumlah tenaga kerja yang lebih besar berarti akan menambah tingkat produksi, sedangkan pertumbuhan penduduk yang lebih besar berarti ukuran pasar domestiknya lebih besar. Meski demikian hal tersebut masih dipertanyakan apakah benar laju pertumbuhan penduduk yang cepat benar-benar akan memberikan dampak positif atau negatif dari pembangunan ekonominya. Selanjutnya dikatakan bahwa pengaruh positif atau negatif dari pertumbuhan penduduk tergantung pada kemampuan sistem perekonomian daerah tersebut dalam menyerap dan secara produktif memanfaatkan pertambahan tenaga kerja tersebut. Kemampuan tersebut dipengaruhi oleh tingkat dan jenis akumulasi modal dan tersedianya input dan faktor penunjang seperti kecakapan manajerial dan administrasi.

Dalam model sederhana tentang pertumbuhan ekonomi, pada umumnya pengertian tenaga kerja diartikan sebagai angkatan kerja yang bersifat homogen. Menurut Lewis, angkatan kerja yang homogen dan tidak terampil dianggap bisa bergerak dan beralih dari sektor tradisional ke sektor modern secara lancar dan dalam jumlah terbatas. Dalam keadaan demikian penawaran tenaga kerja mengandung elastisitas yang tinggi.Meningkatnya permintaan atas tenaga kerja (dari sektor tradisional) bersumber pada ekspansi kegiatan sektor modern.Dengan demikian salah satu faktor yang berpengaruh terhadap pertumbuhan ekonomi adalah tenaga kerja.

Menurut Salvatore (2006) bahwa suatu fungsi produksi suatu barang atau jasa tertentu (Q) adalah $\mathrm{Q}=\mathrm{f}(\mathrm{K}, \mathrm{L})$ dimana $\mathrm{K}$ merupakan modal dan $\mathrm{L}$ adalah tenaga kerja yang memperlihatkan jumlah maksimal suatu barang/jasa yang dapat diproduksi dengan menggunakan kombinasi alternatif antara $\mathrm{K}$ dan $\mathrm{L}$ maka apabila salah satu masukan ditambah satu unit tambahan dan masukan lainnya dianggap tetap akan menyebabkan tambahan keluaran yang dapat diproduksi.

Tambahan keluaran yang diproduksi inilah yang disebut dengan produk fisik marjinal (Marginal Physcal Product). Selanjutnya dikatakan bahwa apabila jumlah tenaga kerja ditambah terus menerus sedang faktor produksi lain dipertahankan konstan, maka pada awalnya akan menunjukkan peningkatan produktivitas namun pada suatu tingkat tertentu akan memperlihatkan penurunanproduktivitasnya serta setelah mencapai tingkat keluaran maksimal setiap penambahan tenaga kerja akan mengurangi pengeluaran.

Simanjuntak (1985) menyebutkan bahwa tenaga kerja adalah mencakup penduduk yang sudah atau sedang bekerja, sedang mencari pekerjaan dan melakukan kegiatan lain, seperti bersekolah dan mengurus rumah tangga.Menurut Badan Pusat Statistik (BPS) penduduk berumur 15 tahun ke atas terbagi sebagai Angkatan Kerja (AK) dan bukan AK.Angkatan Kerja dikatakan bekerja bila mereka melakukan pekerjaan dengan maksud memperoleh atau membantu memperoleh pendapatan atau keuntungan dan lamanya bekerja paling sedikit 1 
(satu) jam secara kontinu selama seminggu yang lalu. Sedangkan penduduk yang tidak bekerja tetapi sedang mencari pekerjaan disebut menganggur.

\section{Investasi dan Pertumbuhan Ekonomi}

Teori ekonomi mengartikan atau mendefinisikan investasi sebagai "pengeluaranpengeluaran untuk membeli barang-barang modal dan peralatan-peralatan produksi dengan tujuan untuk mengganti dan terutama menambah barang-barang modal dalam pereko nomian yang akan digunakan untuk memproduksikan barang dan jasa di masa depan".

Menurut Boediono (1992) investasi adalah pengeluaran oleh sektor produsen (swasta) untuk pembelian barang dan jasa untuk menambah stok yang digunakan atau untuk perluasan pabrik. Persyaratan umum pembangunan ekonomi suatu negara menurut Todaro (1981) adalah:

1. Akumulasi modal, termasuk akumulasi baru dalam bentuk tanah, peralatan fisik dan sumber daya manusia;

2. Perkembangan penduduk yang dibarengi dengan pertumbuhan tenaga kerja dan keahliannya;

3. Kemajuan teknologi.

Akumulasi modal akan berhasil apabila beberapa bagian atau proporsi pendapatan yang ada ditabung dan diinvestasikan untuk memperbesar produk (output) dan pendapatan di kemudian hari. Untuk membangun itu seyogyanya mengalihkan sumber-sumber dari arus konsumsi dan kemudian mengalihkannya untuk investasi dalam bentuk "capital formation" untuk mencapai tingkat produksi yang lebih besar. Investasi di bidang pengem bangan sumber daya manusia akan meningkatkan kemampuan sumber daya manusia, sehingga menjadi tenaga ahli yang terampil yang dapat memperlancar kegiatan produktif.

Menurut Sukirno (2000) kegiatan investasi memungkinkan suatu masyarakat terus menerus meningkatkan kegiatan ekonomi dan kesempatan kerja, meningkatkan pendapatan nasional dan meningkatkan taraf kemakmuran masyarakat. Peranan ini bersumber dari tiga fungsi penting dari kegiatan investasi, yakni :

1. Investasi merupakan salah satu komponen dari pengeluaran agregat, sehingga kenaikan investasi akan meningkatkan permintaan agregat, pendapatan nasional serta kesempatan kerja.

2. Pertambahan barang modal sebagai akibat investasi akan menambah kapasitas produksi.

3. Investasi selalu diikuti oleh perkembangan teknologi.

Dalam praktiknya, dalam usaha untuk mencatat nilai penanaman modal yang dilakukan dalam suatu tahun tertentu, yang digolongkan sebagai investasi (atau pembentukan modal atau penanaman modal) meliputi pengeluaran-pengeluaran sebagai berikut :

1. Pembelian berbagai jenis barang modal, yaitu mesin-mesin dan peralatan produksi lainnya untuk mendirikan berbagai jenis industri dan perusahaan.

2. Pengeluaran untuk mendirikan rumah tempat tinggal, bangunan kantor, bangunan pabrik dan bangunan-bangunan lainnya.

3. Pertambahan nilai stok barang-barang yang belum terjual, bahan mentah dan barang yang masih dalam proses produksi pada akhir tahun perhitungan pendapatan nasional.

Di Indonesia, investasi atau penanaman modal dapat diklasifikasikan menjadi dua bagian, yaitu :

1. Penanaman Modal DalamNegeri (PMDN). PMDN adalah bagian dari kekayaan masyarakat Indonesia termasuk hak-hak dan benda-benda, baik yang dimiliki oleh negara maupun swasta asing yang berdomisili di Indonesia, yang disisihkan/ disediakan guna menjalankan sesuatu usaha sepanjang modal tersebut tidak diatur dalam ketentuan Pasal 2 Undang-Undang No. 1 Tahun 1967 tentang PMA yang mengatur mengenai pengertian 


\section{Volume 18 Nomor 2}

modal asing (Widjaya, 2005: 23). Pihak swasta yang memiliki modal dalam negeri tersebut dapat secara perorangan dan ataupun merupakan badan hukum yang didirikan berdasarkan hukum yang berlaku di Indonesia. PMDN adalah penggunaan kekayaan, baik secara langsung maupun tidak langsung untuk menjalankan usaha menurut ketentuan Undang-Undang Penanaman Modal.

2. Penanaman Modal Asing (PMA). Penanaman Modal Asing yang tercakup hanyalah PMA secara langsung yang dilakukan berdasarkan ketentuan Undang-Undang No.1 Tahun 1967 dan yang digunakanmenjalankanperusahaan di Indonesia, dalamartipemilik modal secara langsung menanggung resiko dari pananaman modal tersebut (Widjaya, 2005). Pengertian modal asing adalah alat pembayaran luar negeri yang tidak merupakan bagian dari kekayaan devisa Indonesia, yang dengan persetujuan pemerintah digunakan untuk pembiayaan perusahaan di Indonesia.

\section{E. Produktivitas Rata-rata (Average Productivity)}

Pada umumnya untuk mengukur produktivitas atau efisiensi masing-masing input, maka digunakan perhitungan dengan produktivitas rata-rata(Average Productivity). Adapun persamaan dari average productivity $(\mathrm{AP})$ padamasing-masing input adalah sebagai berikut :

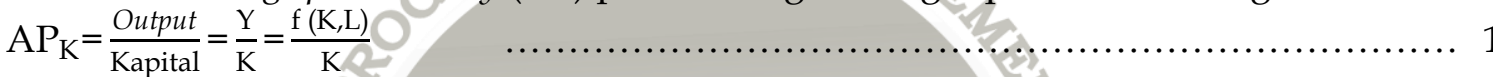

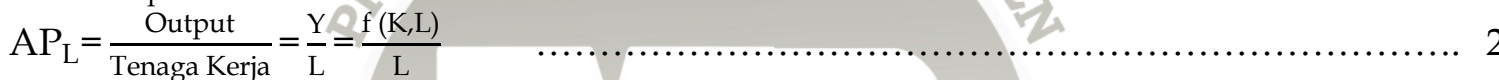

Namun, nilai produktivitas rata-rata (AP) ini dalam jangka panjang akan selalu positif seiring dengan peningkatan inputnya. Sementara penambahan satu unit input ini dalam jangka panjang justru menurunkan produktivitas input lainnya. Hal ini juga berdampak pada penurunan jumlah output yang diproduksi. Oleh karena itu, penggunaan produktivitas ratarata $(\mathrm{AP})$ dalam jangka panjang sebagai proksi dari efisiensi produksi ternyata "kurang tepat". Indikator lain diperlukan untuk melihat tingkat efisiensi setiap tambahan input. Apakah tambahan setiap input ini mampu mendorong mendorong output tumbuh lebih besar, atau bahkan sebaliknya. Produktivitas tambahan (marginal productivity) inilah yang dianggap sebagai indikator yang tepat untuk menggambarkan tingkat efisiensi produksi.

\section{F. Produktivitas Marginal (Marginal Productivity)}

Produktivitas marginal (marginal productivity) adalah tambahan output yang dapat dihasilkan apabila ada tambahan satu atau lebih unit input tertentu dengan mengganggap input lainnya tidak berubah (konstan). Produktivitas marginal ini dibagi menjadi dua jenis berdasarkan input-input yang digunakan dalam fungsi produksi, yaitu produktivitas marginal modal $\left(\mathrm{MP}_{\mathrm{K}}\right)$ dan produktivitas marginal tenaga kerja $\left(\mathrm{MP}_{\mathrm{L}}\right)$. Produktivitas marginal modal $\left(\mathrm{MP}_{\mathrm{K}}\right)$ adalah tambahan output yang dihasilkan dengan adanya tambahan satu lagi unitkapital (misal: mesin) dengan jumlah tenaga kerja tetap. Sementara produktivitas marginal tenaga kerja $\left(\mathrm{MP}_{\mathrm{L}}\right)$ adalah tambahan output yang dihasilkan dengan adanya tambahan satu lagi unit tenaga kerja dengan menganggap tetap tingkat unit kapital. Berikut persamaan produktivitas marginal (MP) pada masing-masing input :

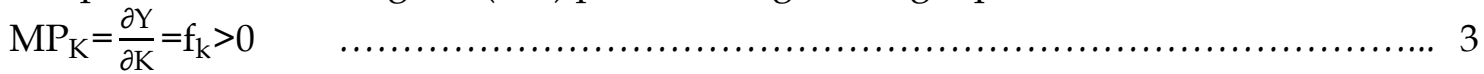

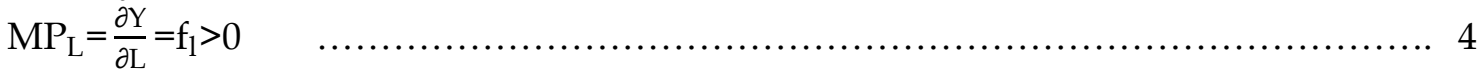

Kedua produktivitas marginal pada masing-masing input ini sama-sama memiliki tanda yang positif $\left(\mathrm{MP}_{\mathrm{x}}>0\right)$. Hal ini berarti bahwa peningkatan pada masing-masing input baik kapital maupun tenaga kerja akan "selalu" meningkatkan outputnya.

\section{G. Total FactorProductivity (TFP)}

Definisi Total Factor Productivity (TFP) adalah proporsi dari out put yang tidak dijelaskan dalam input-input yang digunakan dalam proses produksi, seperti tingkat efisiensi 
input (Comin,2006). TFP merupakan salah satu pendekatan untuk mengukur nilai kemajuan teknologi dalam pertumbuhan ekonomi. Pertumbuhan TFP ini dapat dihitung dengan model "Solow Residual". Persamaan Solow Residualini adalah :

$\left.\frac{\mathrm{d} Y}{\mathrm{Y}}=\propto \frac{\mathrm{dK}}{\mathrm{K}}+\beta \frac{\mathrm{dL}}{\mathrm{L}}+\frac{\mathrm{dA}}{\mathrm{A}}\right)$

$\dot{\mathrm{Y}}=\alpha \dot{\mathrm{K}}+\beta \dot{\mathrm{L}}+\mathrm{A}(12)$

Sehingga nilai pertumbuhan dari kemajuan teknologinya adalah :

$\dot{\mathrm{A}}=\dot{\mathrm{Y}}-\propto \dot{\mathrm{K}}-\beta \dot{\mathrm{L}}$

Dimana adalah pertumbuhan dari output (growth of output); $\dot{K}$ adalah pertumbuhan dari kapital (growth of capital); $\dot{L}$ adalah pertumbuhan dari tenaga kerja (growth of labor); $\dot{A}$ adalah pertumbuhan dari kemajuan teknologi (growth of technical progress); $\alpha$ adalah elastisitas kapital terhadap output, dan $\beta$ adalah elastisitas tenaga kerja terhadap output.

Model Solow ini mampu untuk mengukur pertumbuhan TFP secara akurat apabila memenuhi beberapa asumsi berikut: (i) bentuk fungsi produksinya adalah neoklasik; (ii) berada pada kondisi pasar persaingan sempurna; dan (iii) tingkat pertumbuhan masingmasing input diukur secara akurat. TFP memainkan peran penting terjadinya fluktuasi ekonomi. Pada pendekatan area bisnis, TFP berkorelasi secara kuat dengan output dan jam kerja. Solow (1956) menyatakan bahwa pertumbuhan output perkapita dalam jangka panjang didorong oleh pertumbuhan kemajuan teknologi (TFP). Peran input teknologi yang sangat penting dalam perekonomian ini menarik para pakar ekonomi untuk menghitung penurunannya dari fungsi produksi. Solow memperkenalkan pertama kalinya mengenai penurunan untuk menghitung pertumbuhan kemajuan teknologi disetiap perekonomin. Solow menggunakan pendekatan" growthaccounting"dalam fungsi penurunannya.

\section{H. Growth Accounting}

Solow(1957)memperkenalkansebuahalternativeproductivityindexpadajurnalpenelitiannya yangberjudul "TechnicalChangeandTheAggregateProductionFunction" Solowmenggunakanfungsi produksiCobb-Douglasuntuk menjelaskanmodel alternativeproductivityindex ini. FungsiCobbDouglasadalahsebagai berikut

$$
Y(t)=f(K(t), L(t), A(t)
$$

Dimana(Y)adalahoutput,(K)adalahkapital,(L)adalahtenagakerja, $(A)$ adalahlevelofthetechnology, dan $(t)$ adalahtimeindex.Solowmelakukanpenurunanfungsiproduksinyasebagaiberikut :

$$
\mathrm{Y}(\mathrm{t})=\mathrm{A}(\mathrm{t}) \cdot \mathrm{f}(\mathrm{K}(\mathrm{t}), \mathrm{L}(\mathrm{t}))
$$

Persamaaninikemudiandidiferensialkanterhadap $(t)$.

$$
\begin{aligned}
& \frac{d \mathrm{Y}}{\mathrm{dt}}=\frac{\mathrm{dA}}{\mathrm{dt}} \mathrm{f}+\mathrm{A}_{(\mathrm{t})} \frac{\mathrm{df}}{\mathrm{dK}} \frac{\mathrm{dK}}{\mathrm{dt}}+\mathrm{A}_{(\mathrm{t})} \frac{\mathrm{df}}{\mathrm{dL}} \frac{\mathrm{dL}}{\mathrm{dt}} \\
& \frac{\mathrm{dY}}{\mathrm{dt}}=\widehat{\mathrm{Y}} ; \frac{\mathrm{dK}}{\mathrm{dt}}=\widehat{\mathrm{K}} ; \frac{\mathrm{dL}}{\mathrm{dt}}=\widehat{\mathrm{L}} ; \frac{\mathrm{dA}}{\mathrm{dt}}=\widehat{\mathrm{A}}
\end{aligned}
$$

Tanda cap $(\wedge)$ pada persamaan (15) ini mengindikasikan dari adanya "time derivatives". Sehingga persamaan (15) dapat ditulis menjadi :

$$
\widehat{Y}=\hat{A} f+A_{(t)} \frac{d f}{d K} \widehat{K}+A_{(t)} \frac{d f}{d L} \widehat{L}
$$

Selanjutnya , persamaan (16) dibagi dengan $Y$.

$$
\frac{\widehat{Y}}{Y}=\widehat{A} \frac{f(K, L)}{Y}+A_{(t)} \frac{d f}{d K} \frac{\widehat{K}}{Y}+A_{(t)} \frac{d f}{d L} \frac{\widehat{L}}{Y}
$$

Persamaan (17) dapat ditransformasikan sebagai berikut :

$$
\frac{\widehat{Y}}{\mathrm{Y}}=\frac{\widehat{A}}{\mathrm{~A}}+\mathrm{A}_{(\mathrm{t})} \frac{\mathrm{df}}{\mathrm{dK}} \frac{\widehat{K}}{\mathrm{Y}} \frac{\widehat{K}}{\mathrm{~K}}+\mathrm{A}_{(\mathrm{t})} \frac{\mathrm{df}}{\mathrm{dL}} \frac{\widehat{L}}{\mathrm{Y}} \frac{\widehat{L}}{\mathrm{~L}}
$$

Dimana $\frac{d f}{d K} \frac{K}{Y}=\frac{d Y}{d K} \frac{K}{Y}$ adalah elastisitas output terhadap capital (a) dan $\frac{d f}{d L} \frac{L}{Y}=\frac{d Y}{d L} \frac{L}{Y}$ adalah elastisitas output terhadap tenaga kerja $(\beta)$.Persamaan ini ternyata menghasilkan fungus produk marginal pada masing-masing inputnya,yoitu $\left(\mathrm{MP}_{\mathrm{K}} \frac{\mathrm{df}}{\mathrm{dK}}\right.$ dan $\left.\mathrm{MP}_{\mathrm{L}}=\frac{\mathrm{df}}{\mathrm{dL}}\right)$.

$$
\dot{\mathrm{Y}}=\dot{\mathrm{A}}+\propto \dot{\mathrm{K}}+\beta \dot{\mathrm{L}}
$$


Tanda dot $\left({ }^{\circ}\right)$ ini mengindikasikan dari pertumbuhan masing-masing komponen. Notasi dari $Y$ adalah pertumbuhan dari output (growth of output); $K$ adalah pertumbuhan dari kapital (growth of capital); $L$ adalah pertumbuhan dari tenaga kerja (growth of labor); $A$ adalah pertumbuhan dari kemajuan teknologi (growth of technical progress); $\alpha$ adalah elastisitas kapital terhadap output, dan $\beta$ adalah elastisitas tenaga kerja terhadap output. Sehingga persamaan "Solow Residual" yang merefleksikan dari adanya technical change ini dapat diperoleh sebagai berikut :

$\dot{\mathrm{A}}=\dot{\mathrm{Y}}-\propto \dot{\mathrm{K}}-\beta \dot{\mathrm{L}}$

Persamaan (18) ini jika diaplikasikan pada data riil berbagai periode waktu, maka dapat diturunkan ke persamaan berikut :

$$
\frac{\Delta \mathrm{A}_{\mathrm{t}}}{\mathrm{A}_{\mathrm{t}-1}}=\frac{\Delta \mathrm{Y}_{\mathrm{t}}}{\mathrm{Y}_{\mathrm{t}-1}} \propto \frac{\Delta \mathrm{K}_{\mathrm{t}}}{\mathrm{K}_{\mathrm{t}-1}}-\beta \frac{\Delta \mathrm{L}_{\mathrm{t}}}{\mathrm{L}_{\mathrm{t}-1}}
$$

Persamaan (19) ini yang merupakan salah satu penerapan persamaan pertumbuhan atau yang dikenal dengan "Growth Accounting" untuk menghitung nilai pertumbuhan input teknologi (TFP).

\section{Hipotesis Penelitian}

Berdasarkan rumusan masalah, tujuan penelitian, dan kerangka pikir maka menghasilkan beberapa hipotesis seperti berikut :

Tingkat Investasi dan angkatan kerja berpengaruh positif dan signifikan terhadap pertumbuhan PDRB di Indonesia Tahun 2011-2014

\section{METODOLOGI}

\section{A. Ruang Lingkup Penelitian}

Ruang lingkup penelitian ini adalah 33 provinsi yang berada di Indonesia. Sementara itu Provinsi Kalimantan Utara yang baru terbentuk pada tahun 2012 berdasarkan Undangundang Nomor 20 Tahun 2012 tidak diikut sertakan sebagai sampel penelitian karena terkendala ketersediaan data.Variabel yangdigunakan dalam penelitian ini berjumlah tiga variabel, dengan dua variabelindependen dan satu variabel dependen. Variabel dependen yang digunakan yaitu nilai Produk Domestik Regional Bruto Lapangan Usaha Atas Dasar Harga Konstan 2010. Variabelindependen yang digunakan yaitu angkatan kerja, Penanaman Modal Asing dan Penanaman Modal Dalam Negeri.

\section{B. Metode Pengumpulan Data}

Data yang digunakan pada penelitian ini yang digunakan adalah datapanel yang merupakan gabungan dari data cross section dan data time series. Datacross section yang digunakan berdasarkan jumlah provinsi di Indonesia yaitu 33 provinsi. Untuk data time series, data yang digunakan adalahdata tahunan dan periode yang digunakan mulai dari tahun 2011 hingga 2014.

Data yang digunakan dalam penelitian ini adalah data sekunder yangdidapatkan dari berbagai sumber, yaitu dari Badan Pusat Statistik (BPS), BankIndonesia (BI), Badan Koordinasi Penanaman Modal (BKPM), dan Kementrian Lingkungan Hidup dan Kehutanan Republik Indonesia. Data yangdigunakan adalah sebagai berikut:

1. Produk Domestik Regional Bruto (PDRB). Pada penelitian ini menggunaan PDRB berdasarkan Lapangan Usaha Atas Dasar Harga Konstan 2010 yang diperoleh dari Badan Pusat Statistik. Produk Domestik Regional Bruto berdasarkan Lapangan Usaha merupakan penghitungan PDRB dengan pendekatan produksi yang diperoleh dari penjumlahan nilai tambah dari 17 klasifikasi lapangan usaha berdasarkan System of National Accounts (SNA) 2008.

2. Penanaman Modal Asing (PMA) dan Penanaman Modal Dalam Negeri (PMDN). Penamana Modal Asing merupakan nilai realisasi PMA pada setiap provinsi yang berada 
di Indonesia. Nilai realisasi yang dimaksud adalah nilai modal yang telah ditanamoleh penanam modal asing, baik yang mengunakan modal asing sepenuhnyamaupun yang berpatungan dengan penanam modal dalam negeri dan Penanaman Modal Dalam Negeri merupakan nilai modal yang telah ditanam dan disetujui oleh penanam modal dalam negeri. Data diperoleh dari Badan Koordinasi Penanaman Modal.

3. Angkatan Kerja (AK). Angkatan Kerja di Indonesia merupakan penduduk dengan usia diatas 15 tahun yang sudah bekerja, belum bekerja, maupun yang sedang mencari pekerjaan.Data angkatan kerja diperoleh dari Badan Pusat Statistik (Publikasi Keadaan Angkatan Kerja Indonesia).

\section{Metode Analisis} berikut :

Dalam penelitian ini menggunakan dua model regresi dengan data panel sebagai

$\operatorname{LnPDRB}_{i t}=\left(\beta_{0}+U_{i}\right)+\beta_{1}$ LnInvestasi $_{i t}+\beta_{2}$ LnAngkatanKerja $_{i t}+\varepsilon_{i t}$

Keterangan:

i : Provisi ke-I (provinsi di Indonesia)

$\mathrm{t}$ : waktu ke-t (tahun)

Investasi

Angkatan Kerja

$\beta_{0}$

$\beta_{1}, \beta_{2}$

$\varepsilon_{\text {it }}$

= Realisasi PMA + Realisasi PMDN (miliar rupiah)

= Angkatan Kerja (orang)

= Konstanta

= Koefisien Regresi

$=$ Komponen Error

Setelah mendapatkan koefisien regresi masing-masing variabel bebas, selanjutnya penghitungan Total Factor Productivity menggunakan Growth Accounting :

$\operatorname{LnTFP}_{i t}=\operatorname{LnPDRB_{it}}-\left(\beta_{0}+\beta_{1}\right.$ LnInvestasi $_{i t}+\beta_{2}$ LnAngkatanKerja $\left.{ }_{i t}\right)$

\section{HASIL DAN PEMBAHASAN}

Pertumbuhan ekonomi adalah proses perubahan perekonomian suatu negara secara berkesinambungan menuju keadaan yang lebih baik selama periode tertentu. Pertumbuhan ekonomi juga dapat diartikan juga sebagai proses kenaikan kapasitas produksi suatu perekonomian suatu negara. Perumbuhan ekonomi Indonesia secara rinci dari tahun ke tahun, disajikan melalui Produk Domestik Bruto (PDB) atas dasar harga konstan. Pada penelitian ini, pertumbuhan ekonomi digambarkan malalui pertumbuhan PDB atas dasar harga konstan tahun 2010 dari tahun 2010 hingga tahun 2014.

Selama periode 2010 hingga tahun 2014 pertumbuhan ekonomi d Indonesia selalu mengalami peningkatan rata-rata 5,82 persen per tahun. Peningkatan PDB yang paling tinggi terjadi pada tahun 2011 (6,15 persen), dan yang paling rendah adalah tahun 2014 (5,20 persen). Jadi, pertumbuhan ekonomi di Indonesia mulai tahun 2013 mengalami perlambatan pertumbuhan dibandingkan tahun-tahun sebelumnya. Kondisi ini disebabkan penurunan sumbangan sektor industri dan sektor pertambangan yang masing-masing hanya mengalami pertumbuhan 0,2 dan 0,05 persen pada tahun 2014. Hal ini merupakan suatu kemunduran apabila dibandingkan pada tahun 2011, kedua sektor ini mengalami pertumbuhan sebesar 6,26 dan 4,29 persen. Adapun Produk Domestik Bruto Atas Dasar Harga Konstan 2010 di Indonesia Tahun 2010-2014 (Miliar Rupiah) disajikan pada Gambar 3 berikut. 


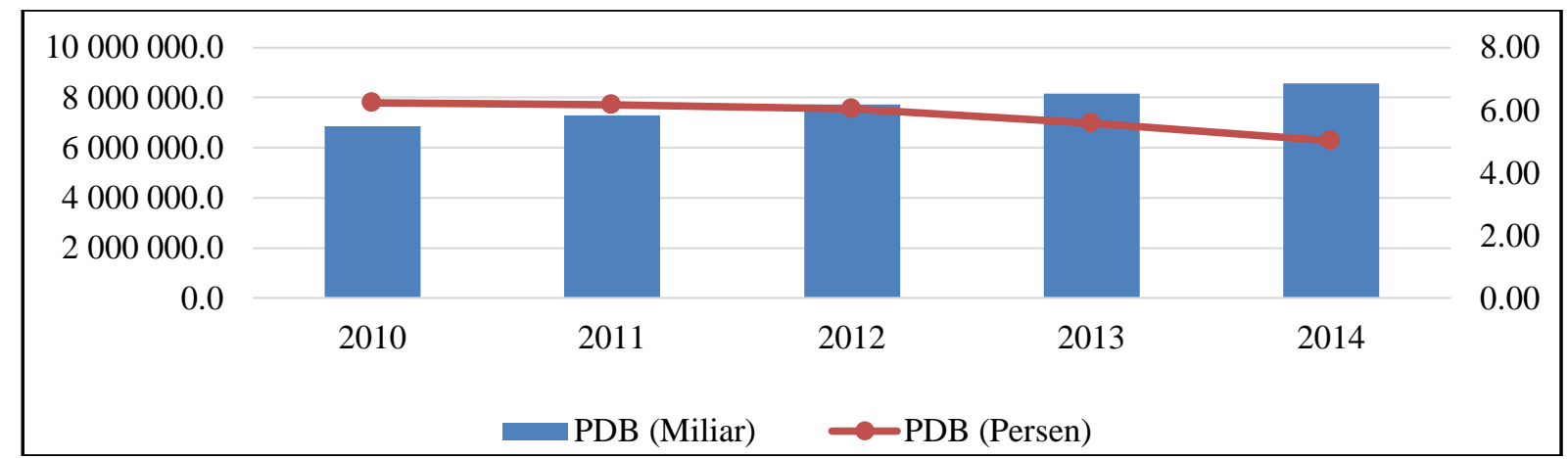

Gambar 3. Produk Domestik Bruto Atas Dasar Harga Konstan 2010 di Indonesia Tahun 20102014 (Miliar Rupiah)

Sumber: Badan Pusat Statistik,diolah

Selaras dengan kondisi nasional yang menginginkan pembangunan melalui pertumbuhan ekonomi, seluruh provinsi tentunya menginginkan dan menjadikan pertumbuhan ekonomi menjadi salah satu sasaran dalam pembangunan provinsinya. Produk Domestik Regional Bruto menggambarkan kemampuan suatu wilayah dalam menciptakan nilai tambah pada suatu waktu tertentu.Pada gambar yang disajikan akan ditampilkan PDRB dari sisi produksi yang merupakan penjumlahan seluruh nilai tambah bruto yang mampu diciptakan oleh sektor-sektor ekonomi atas berbagai aktivitas produksinya.

Pada Gambar 3, provinsi yang memiliki jumlah PDRB tertinggi di Indonesia adalah Provinsi DKI Jakarta pada tahun 2014. Struktur ekonomi DKI Jakarta sangat didominasi oleh ekonomi sektor tersier (jasa) atau dikenal juga dengan sektor non-tradeable. Kelompok ekonomi tersier Provinsi DKI Jakarta menyumbang 72,39\% dari total PDRB Provinsi DKI Jakarta pada tahun 2014. Selama tahun 2010 hingga tahun 2014 rata-rata PDRB yang tercipta per tahun di DKI Jakarta adalah 1.395,5 triliun rupiah. Pertumbuhan ekonomi DKI Jakarta pada satu dekade terkahir selalu lebih tinggi yaitu sebesar 6,33 persen dari pertumbuhan nasional sebesar 5,8 persen yang menjadikan Provinsi DKI Jakarta sebagai penggerak perekonomian nasional. Aapun Produk Domestik Regional Bruto di 33 Provinsi Indonesia tahun 2014 (Miliar Rupiah) pada Gambar 4 beriktu.

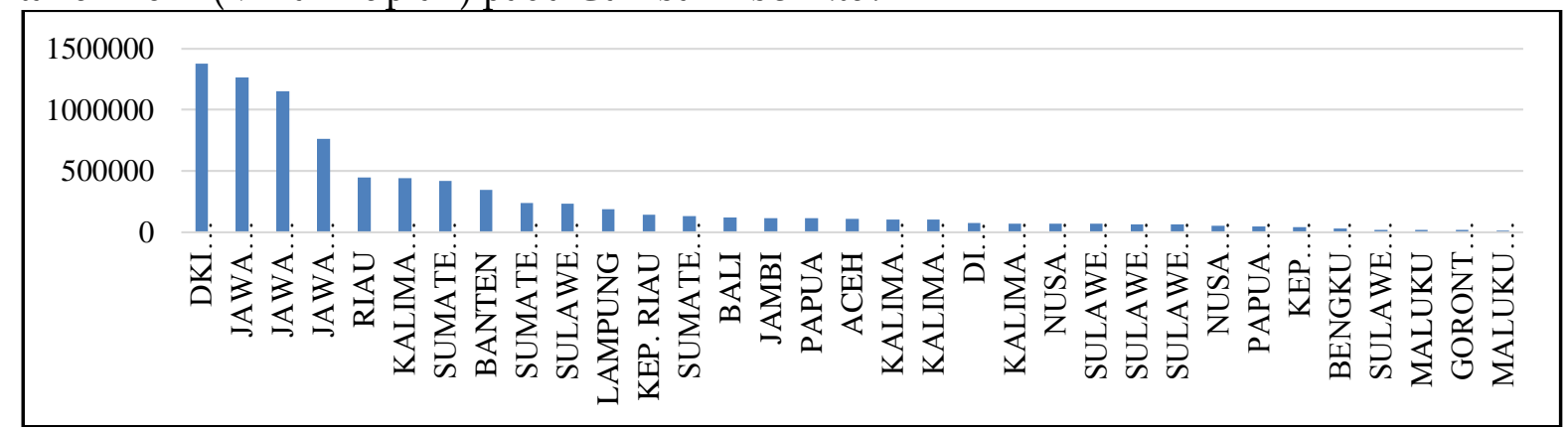

Gambar 4. Produk Domestik Regional Bruto di 33 Provinsi Indonesia tahun 2014 (Miliar Rupiah)

Sumber: Badan Pusat Statistik,diolah

Provinsi yang memiliki Produk Domestik Regional Bruto terendah pada tahun 2014 adalah Provinsi Maluku Utara. Hal ini disebabkan berkurangnya nilai tambah pertambangan bijih logam di Maluku Utara tahun 2014 sebesar 13,05 persen. Ini merupakan dampak diberlakukannya Undang-Undang Minerba yaitu pelarangan ekspor bahan mineral mentah. Namun, apabila dilihat dari rata-rata pertumbuhan PDB Provinsi Maluku Utara dari tahun 
2010 hingga tahun 2014 sebesar 6,41 persen lebih tinggi dibandingkan pertumbuhan PDB secara nasional.

Seperti halnya pertumbuhan ekonomi di Indonesia, perkembangan investasi di Indonesia dari tahun 2010 hingga tahun 2014 selalu mengalami peningkatan. Investasi tertinggi dicapai pada tahun 2014 dengan total sebanyak 493.081 miliar rupiah. Hal ini sangat baik mengingat bagaimana pentingnya peran investasi dalam membantu meningkatkan pembangunan nasional. Keadaan investasi di Indonesia tidak lepas dari peran Penanaman Modal Asing dan Penanaman Modal Dalam Negeri. Laju pertumbuhan PMDN di Indonesia selalu lebih tinggi dibandingkan dengan laju pertumbuhan PMA di Indonesia. Laju pertumbuhan PMA Indonesia pada tahun 2014 sebesar 21,83 persen sedangkan PMA Indonesia hanya sebesar 13,07 persen yang disajikan pada pada Gambar 5 berikut.

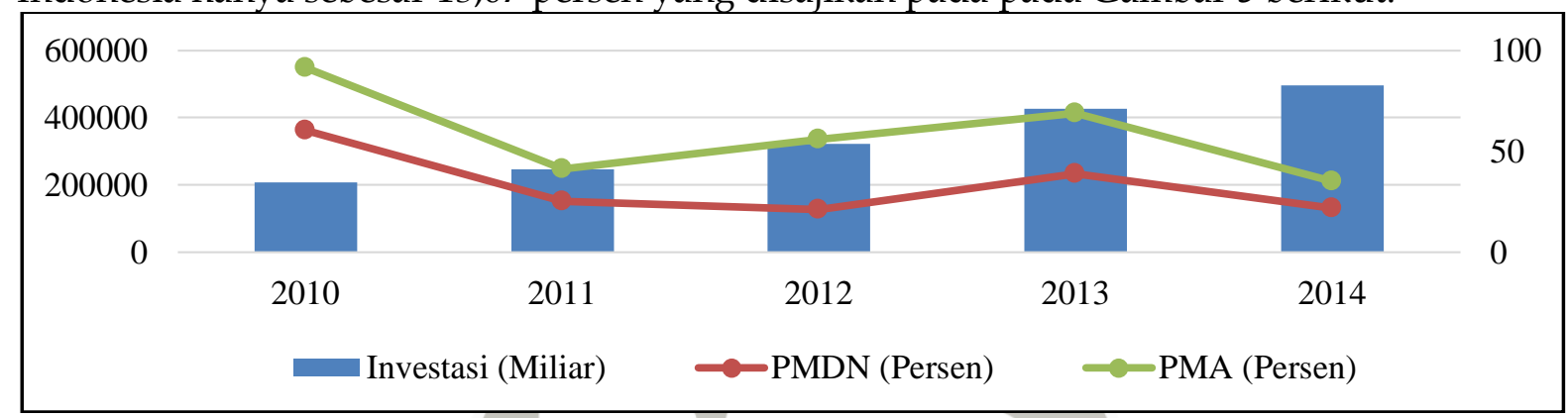

Gambar 5. Perkembangan Investasi di Indonesia Tahun 2010-2014 (Miliar Rupiah) Sumber: Badan Koordinasi Penanaman Modal,diolah

Indonesia terdiri dari beberapa provinsi dengan kondisi dan potensi geografis dan alam yang relative berbeda. Hal tersebut menyebabkan nilai realisasi penanaman modal dalam negeri di tiap provinsi berbeda-beda pula. Perkembangan PMDN pada sebagian besar provinsi cenderung fluktuatif. Hanya terdapat tiga provinsi di Indonesia yang memiliki realisasi penanaman modal dalam negeri yang terus meningkat dari tahun 2010 hingga tahun 2014. Adapun ketiga provinisi itu adalah Jawa Timur, Jawa Tengah, dan Bangka Belitung. Diantara ketiga provinsi tersebut, Provinsi Jawa Timur merupakan provinsi yang memiliki perkembangan realisasi penanaman modal dalam negeri paling pesat setiap tahunnya. Ratarata realisasi penanaman modal dalam negeri yang dihasilkan oleh setiap provinsi di Indonesia ditunjukkan oleh Gambar 6 berikut.

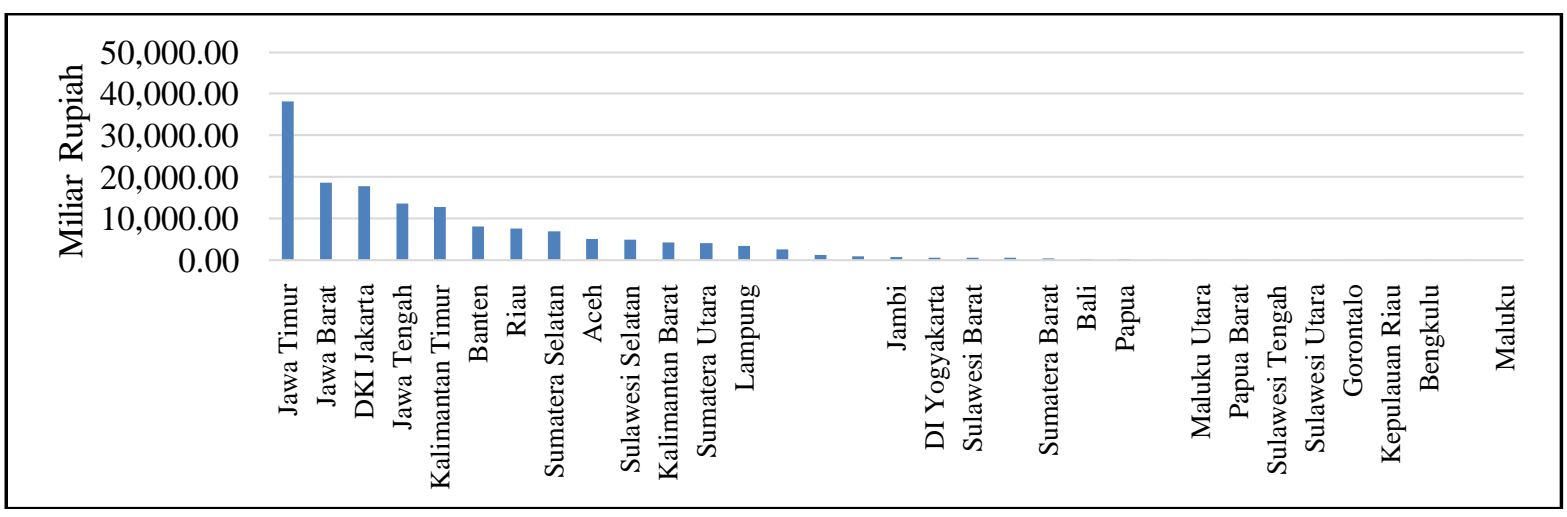

Gambar 6. Penanaman Modal Dalam Negeri di Indonesia 2014

Sumber: Badan Koordinasi Penanaman Modal, diolah

Terlihat pada Gambar 10, bahwa provinsi yang memiliki rata-rata realisasi PMDN tertinggi di Indonesia pada periode 2010 hingga tahun 2014 adalah Provinsi Jawa Timur. Hal tersebut didukung oleh fasilitas Pelayan Terpadu Satu Pintu (PTSP) Jawa Timur yang telah 
mendapat penghargaan sebagai penyelenggara terbaik pertama PTSP di Indonesia yang bersaing dengan 130 PTSP di bidang penanaman modal lainnya.

Hal tersebut membuat para investor dalam negeri lebih cenderung menanamkan modalnya di Jawa Timur mengingat kebijakan PTSP bersifat mempermudah proses penanaman modal.Sedangkan provinsi yang memiliki rata-rata realisasi PMDN terendah di Indonesia pada periode 2010 hingga tahun 2014 adalah Provinsi Maluku. Hal ini disebabkan masih rendahnya infrastruktur di provinsi ini yang menyebabkan investor dalam negeri tidak menanamkan modal di Provinsi Maluku.

Investasi di Indonesia digolongkan atas investasi dalam negeri dan investasi asing yang sering disebut juga Penanaman Modal Asing. Investasi asing sendiri digolongkan kembali menjadi dua jenis yaitu investasi portofolio dan investasi langsung. Portofolio merupakan investasi yang dilakukan melalui pasar modal dengan instrumen surat berharga seperti saham atau obligasi. Sementara itu, PMA merupakan investasi yang dilakukan melalui membangun, membeli total atau akusisi perusahaan. Penanaman Modal Asing memiliki keunggulan dibandingkan portofolio selain sifatnya yang jangka panjang, juga dapat menerapkan proses alih teknologi, keterampilan manajemen serta membuka lapangan usaha baru.

Penanaman Modal Asing (PMA) selalu mengalami peningkatan dari tahun 2010 hingga tahun 2014. Pada tahun 2014, Penanaman Modal Asing di Indonesia mencapai 28.421,20 juta US\$. Tahun 2014 ini juga Indonesia tercatat memiliki pertumbuhan Penanaman Modal Asing tertinggi di kawasan Asing Tenggara. Sektor yang paling diminati oleh investor asing antara lain, pertambangan, transportasi dan telekomunikasi, logam, kimia dasar, serta farmasi. Namun apabila dibandingkan dengan negara tetangga, Singapura sebagai contoh, Indonesia masih jauh tertinggal dari Penanaman Modal Asing di Singapura yang sudah mencapai 67.500 juta US\$. Sehingga, Indonesia masih harus melakukan perbaikan di dalam negeri agar investor menanamkan modalnya di Indonesia. Adapun Penanaman Modal Asing di Indonesia tahun 2010-2014 ( Juta US\$)

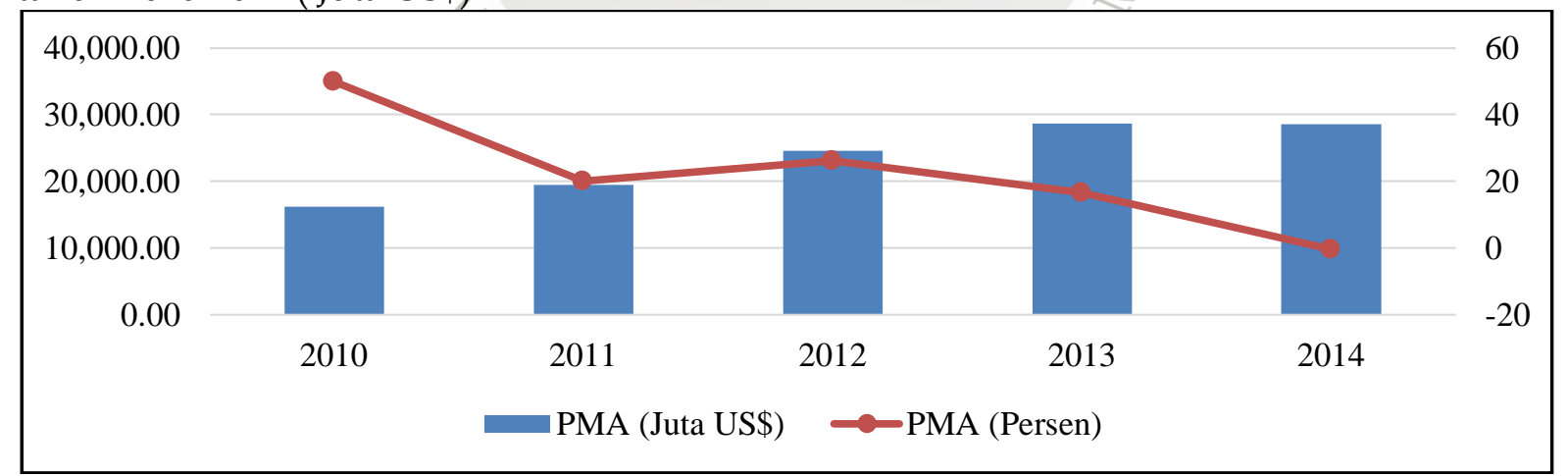

Gambar 7. Penanaman Modal Asing di Indonesia tahun 2010-2014 ( Juta US\$)

Sumber: Badan Koordinasi Penanaman Modal, diolah

Terlihat pada Gambar 12, bahwa pada periode tahun 2010 hingga tahun 2014, dominasi PMA secara rata-rata terdapat di empat provinsi yaitu DKI Jakarta, Jawa Barat, Banten, dan Jawa Timur. Secara rata-rata dari tahun 2010 hingga tahun 2014, PMA tertinggi diperoleh oleh Provinsi Jawa Barat sebesar 4685,8 juta US\$. Jenis sektor usaha yang paling diminati Investor PMA masih disekitar Industri Logam, Mesin dan Elektronik dengan jumlah 18 proyek. Minat investasi ini didasarkan kepada segmen pasar yang cenderung bergerak dinamis disektor tersebut, seperti produk penunjang alat telekomunikasi dan informasi dan kebutuhan konsumen yang meningkat terus. 


\section{Volume 18 Nomor 2}

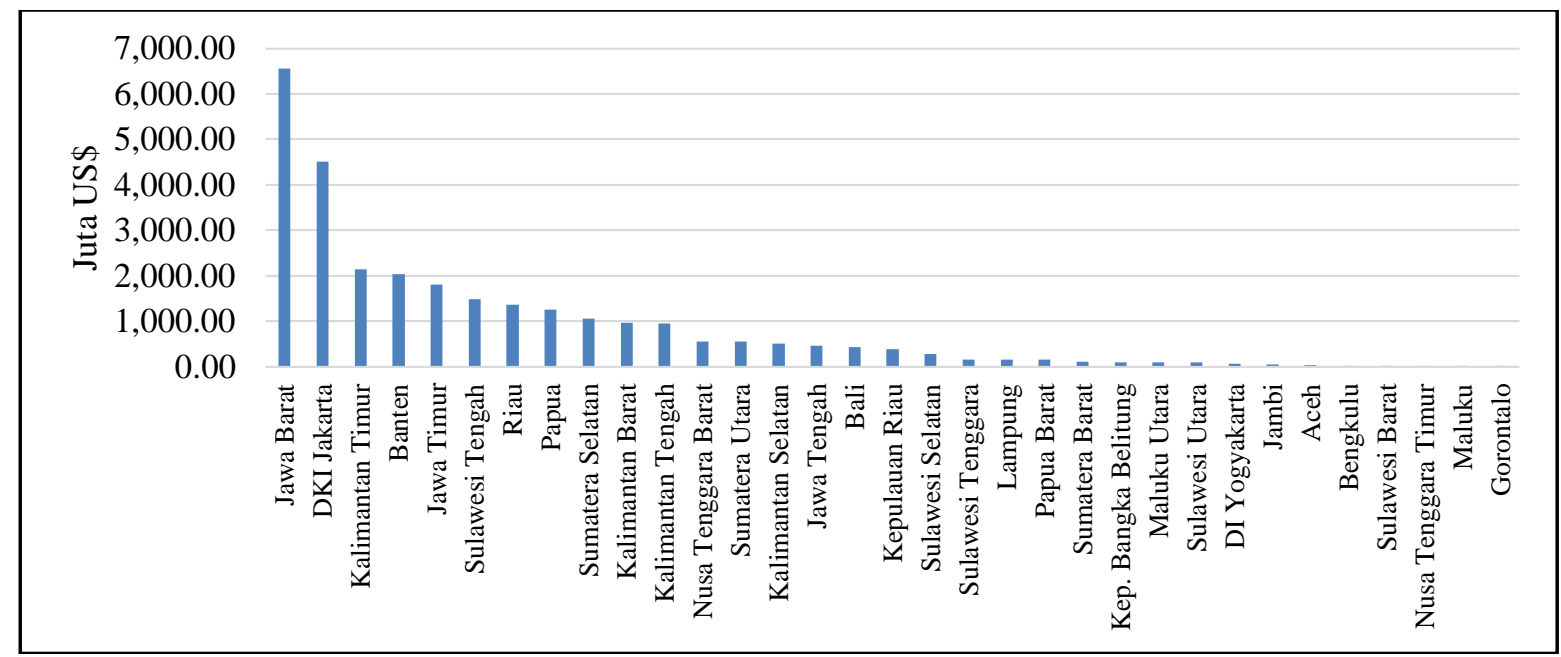

Gambar 8. Penanaman Modal Asing di Indonesia tahun 2014 (juta US\$)

Sumber: Badan Koordinasi Penanaman Modal, diolah

Perkembangan jumlah angkatan kerja di Indonesia selama periode 2010 hingga 2014 dapat dikatakan meningkat kecuali pada tahun 2011 mengalami penurunan dari tahun sebelumnya. Namun,kembali meningkat sejak tahun 2012 hingga tahun 2014. Secara rata-rata, jumlah angkatan kerja tumbuh sebesar 1,13 persen setiap tahunnya dan mencapai pertumbuhan tertinggi pada tahun 2014 sebesar 1,41 persen.

Sedikit berbeda dengan kondisi angkatan kerja di Indonesia secara agregat, angkatan kerja di setiap provinsi Indonesia mengalami fluktuasi. Sebagian besar provinsi di Indonesia selalu mengalami peningkatan angkatan kerja. Hanya beberapa provinsi yang mengalami penurunan jumlah angkatan kerja pada tahun 2014 seperti Provinsi Sumatera Utara, DKI Jakarta dan Jawa Timur. Namun apabila dilihat secara rata-rata, Provinsi Jawa Barat secara rata-rata memiliki jumlah angkatan kerja tertinggi di Indonesia periode 2010 hingga 2014 sebesar 20 juta jiwa. Hal ini wajar mengingat banyaknya industri padat karya yang berdiri di Provinsi Jawa Barat sehingga hal ini menyerap tenaga kerja lebih banyak di provinsi tersebut. Adapun Rata-Rata Jumlah Angkatan Kerja Tahun 2010-2014 disajikan pada Gambar 9 berikut.

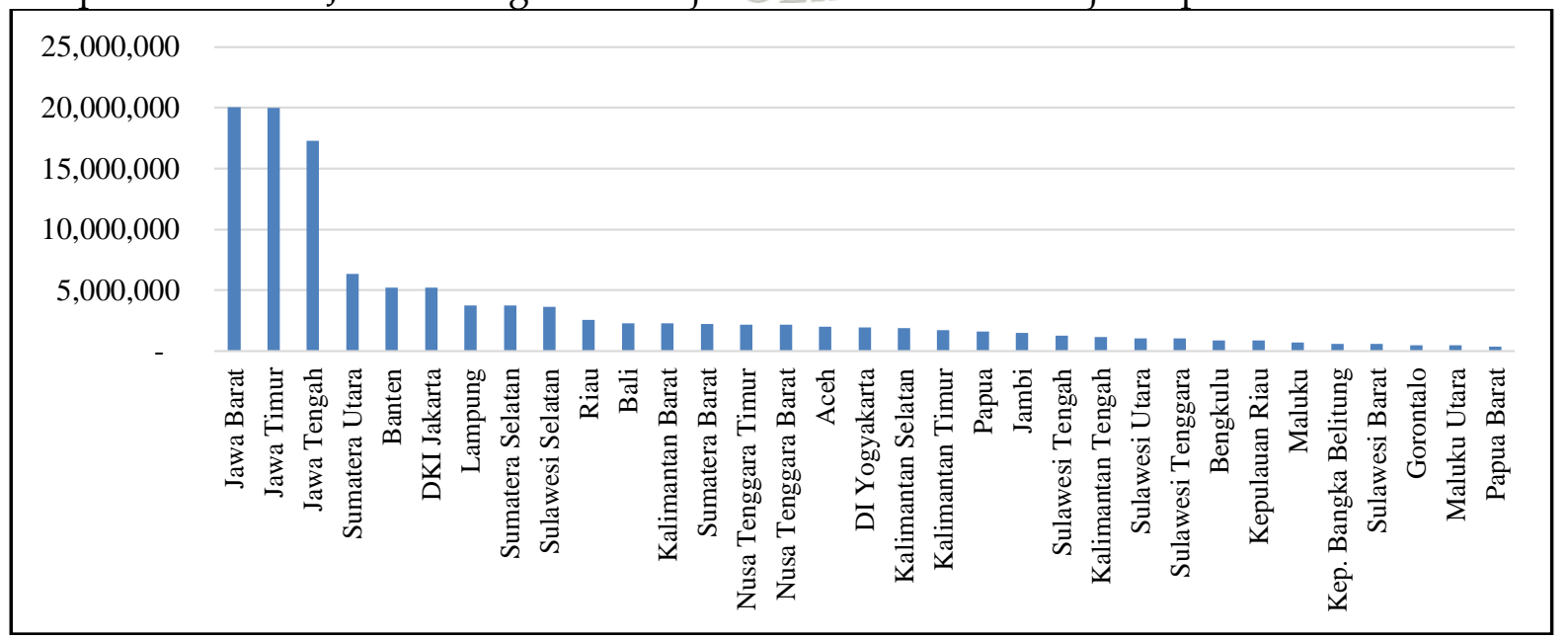

Gambar 9. Rata-Rata Jumlah Angkatan Kerja Tahun 2010-2014

Sumber : BPS, diolah

\section{A. Uji Signifikansi Chow}

Pengujian dilakukan untuk mengetahui apakah teknik regresi data panel menggunakan fixed effects lebih baik daripada common effects. Berdasarkan hasil pengolahan dengan menggunakan Eviews 8.0 diperoleh nilai P-Value sebesar 0,0000 pada kedua model 
pertumbuhan ekonomi . Nilai tersebut lebih kecil daripada tingkat signifikansi alpha 5 persen maka hipotesis nol dapat ditolak. Artinya intersep setiap provinsi adalah berbeda atau dapat dikatakan bahwa model fixed effects lebih baik daripada common effects.

\section{B. Uji Signifikansi Hausman}

Pengujian dilakukan untuk memilih model terbaik antara fixed effects dengan random effects. Berdasarkan hasil pengolahan dengan menggunakan Eviews 8.0 diperoleh nilai PValue sebesar 0,0000 pada kedua model pertumbuhan ekonomi. Nilai tersebut lebih kecil daripada tingkat signifikansi alpha 5 persen, maka hipotesis nol dapat ditolak yang berarti model fixed effects lebih baik baik daripada random effects. Dari hasil pemilihan model tersebut, dapat disimpulkan bahwa model terbaik pertumbuhan ekonomi baik dengan dan tanpa variabel lingkungan adalah fixed effect model.

\section{Pengujian Sruktur Varians-Covarians Residual Asumsi Homoskedastik}

Pengujian selanjutnya adalah pengujian struktur varians-covarians residual setelah didapatkan bahwa model terbaik adalah dengan menggunakan fixed effects model. Pengujian ini dilakukan dengan uji LM (Langrange Multiplier). Berdasarkan hasil pennghitungan, nilai LM-statistics sebesar 47,45 untuk model pertumbuhan ekonomi tanpa variabel lingkungan dan 61,006 untuk model dengan variabel lingkungan yang lebih besar dari nilai $\chi^{2}(0,05 ; 32)$ sebesar 46,19 sehingga dapat diambil kesimpulan bahwa hipotesis nol dapat ditolak pada tingkat signifikansi alpha 5 persen. Artinya, fixed effects model dengan struktur varianskovarians yang bersifat heteroskedastik lebih baik digunakan dibandingkan struktrur varianscovarians yang bersifat homoskedastik.

\section{Pemilihan Estimator Struktur Heteroskedastik dan Tidak adanya Cross Sectional Correlation atau Seemingly Unrelated Regression (SUR)}

Pengujian dilakukan dengan $\lambda_{\mathrm{LM}}$-statistik dan dilakukan apabila pada pengujian struktrur varians-kovarians menunjukkan hasil bahwa model memiliki struktur

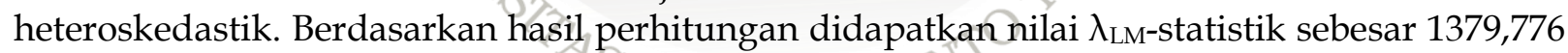
untuk model pertumbuhan ekonomi tanpa variabel lingkungan dan 1073,285 untuk model dengan variabel lingkungan yang lebih besar daripada nilai $\chi^{2}(0,05 ; 528)$ sebesar 582,56. Kesimpulannya bahwa hipotesis nol ditolak pada signifikansi alpha 5 persen, artinya terpilih model fixed effects dengan struktrur varians-covarians yang bersifat heteroskedastik dan ada cross sectional correlation atau seemingly unrelated regression (SUR).

\section{E. Asumsi Nonmultikolinearitas}

Nilai matriks korelasi antara tingkat investasi dan angakatan kerja adalah sebesar 0,64 (lebih kecil dari 0,80) yang menunjukkan tidak terjadinya mulikolinearitas telah terpenuhi.

Berdasarkan hasil pemilihan model terbaik, model yang digunakan adalah fixed effect dengan struktur varians-covarians bersifat heteroskedastik dan adanya cross sectional correlation atau seemingly unrelated regression (SUR). Hasil regresi menunjukkan dengan tingkat signifikansi alpha 5 persen secara bersama-sama (overall test) semua variabel bebas yang terdapat dalam model berpengaruh signifikan terhadap pertumbuhan ekonomi di Indonesia baik tanpa dan dengan variabel lingkungan. Hal ini dapat terlihat dari nilai probabilita statistik F sebesar 0,0000.

Tabel 6. Ringkasan estimasi regresi data panel model fixed effects dengan struktur heteroskedastik dan ada Cross Sectional Correlation (SUR) Model Pertumbuhan Ekonomi tanpa Variabel Lingkungan

\begin{tabular}{|c|c|c|c|c|}
\hline Variabel & Koefisien & t-Statistic & Prob. & Adj. $\mathbf{R}^{\mathbf{2}}$ \\
\hline $\mathbf{( 1 )}$ & $\mathbf{( 2 )}$ & $\mathbf{( 3 )}$ & $\mathbf{( 4 )}$ & $\mathbf{( 5 )}$ \\
\hline C & $-3,518487$ & $-9,026716$ & 0,0000 & 0,999539 \\
\hline
\end{tabular}


Volume 18 Nomor 2

\begin{tabular}{|c|c|c|c|c|}
\hline Variabel & Koefisien & t-Statistic & Prob. & Adj.R $^{\mathbf{2}}$ \\
\hline $\mathbf{( 1 )}$ & $\mathbf{( 2 )}$ & $\mathbf{( 3 )}$ & $\mathbf{( 4 )}$ & $\mathbf{( 5 )}$ \\
\hline LNINVESTASI & 0,033492 & 8,187022 & 0,0000 & \\
\hline LNAK & 1,489122 & 56,87482 & 0,0000 & \\
\hline
\end{tabular}

Keterangan: Signifikansi pada alpha 5\%

Sumber: Hasil pengolahan Eviews 8.0 (Lampiran 8)

Setelah semua uji asumsi model terpenuhi, maka dapat disimpulkan bahwa model yang digunakan sudah bersifat Best Linier Unbiased Estimator (BLUE). Selanjutnya dilakukan interpretasi dari hasil ditas. Nilai adjusted R-square sebesar 0,999937 menunjukkan bahwa 99,993 persen variabel output dijelaskan oleh variabel investasi dan angkatan kerja sedangkan sisanya dijelaskan oleh variabel lain di luar model. Berdasarkan hasil pemilihan model terbaik, maka didapatkan model sebagai berikut:

$$
\text { LNPDRB }=\left(-3,518487+u_{i}\right)+0,033492 \text { LNIVEST ASI }+1,489122 \text { LNAK }
$$

Koefisien untuk investasi yang selanjutnya disebut elastisitas kapital atau elastisitas investasi adalah 0,0334, artinya bahwa setiap kenaikan investasi sebanyak 1 persen, dengan diasumsikan cateris paribus, maka Produk Domestik Regional Bruto akan naik sebesar 0,03 persen. Koefisien angkatan kerja yang selanjutnya disebut elastisitas tenaga kerja nilainya adalah 1,489 artinya bahwa setiap kenaikan input tenaga kerja sebanyak 1 persen, dengan diasumsikan cateris paribus, maka akan menaikkan nilai Produk Domestik Regional Bruto 1,48 persen.

Dari penjelasan diatas, elastisitas dari angkatan kerja lebih besar daripada elastisitas dari investasi. Hal ini dapat kita simpulkan bahwa penambahan tenaga kerja lebih efektif dalam menaikkan pertumbuhan ekonomi di Indonesia dibandingkan menambah investasi di Indonesia. Hal ini sangat wajar dikarenakan proses produksi di Indonesia memang masih bersifat padat karya dibandingkan padat modal.

F. Analisis Pertumbuhan Total Factor Productivity (TFP) dengan metode Growth Accounting dan Green Total Factor Productivity (GTFP) dengan metode Green Growth Accounting

Pertumbuhan Total Factor Productivity (TFP) dihitung sebagai jumlah pertumbuhan yang tersisa (residu) setelah dikurangkan dengan pertumbuhan masing-masing input (faktor produksi) yang terukur. Pertumbuhan input capital (investasi) dan tenaga kerja ini sebelumya dikalikan terlebih dahulu dengan koefisiennya masing-masing yang diperoleh dari hasil estimasi menggunakan regresi data panel model fixed effects dengan struktur heteroskedastik dan ada Cross Sectional Correlation (SUR).

Analisis pertumbuhan TFP digunakan untuk melihat peran faktor produksi selain kapital dan tenaga kerja, yang bias disebut kemajuan teknologi yang menunjukkan kompetensi organisasi, besarnya penelitian dan pengembangan serta kemampuan manajerial (Felipe,1997). Pada penelitian ini, pertumbuhan TFP dihitung dengan menggunakan metode Growth Accounting.

Green Total Factor Productivity adalah metode penghitungan produktivitas yang memperhatikan atau memperhitungkan aspek lingkungan hidup. Pertumbuhan Total Factor Productivity (TFP) dihitung sebagai jumlah pertumbuhan yang tersisa (residu) setelah dikurangkan dengan pertumbuhan masing-masing input (faktor produksi) yang terukur dengan kualitas lingkungan. Jadi, Green Total Factor Productivity memliki makna sebagai seberapa efisien suatu daerah dalam menggunakan faktor input dalam meningkatkan produksi dalam hal ini pertumbuhan ekonomi dan menyeimbangkan dengan kualitas lingkungan daerah tersebut secara bersamaan. 


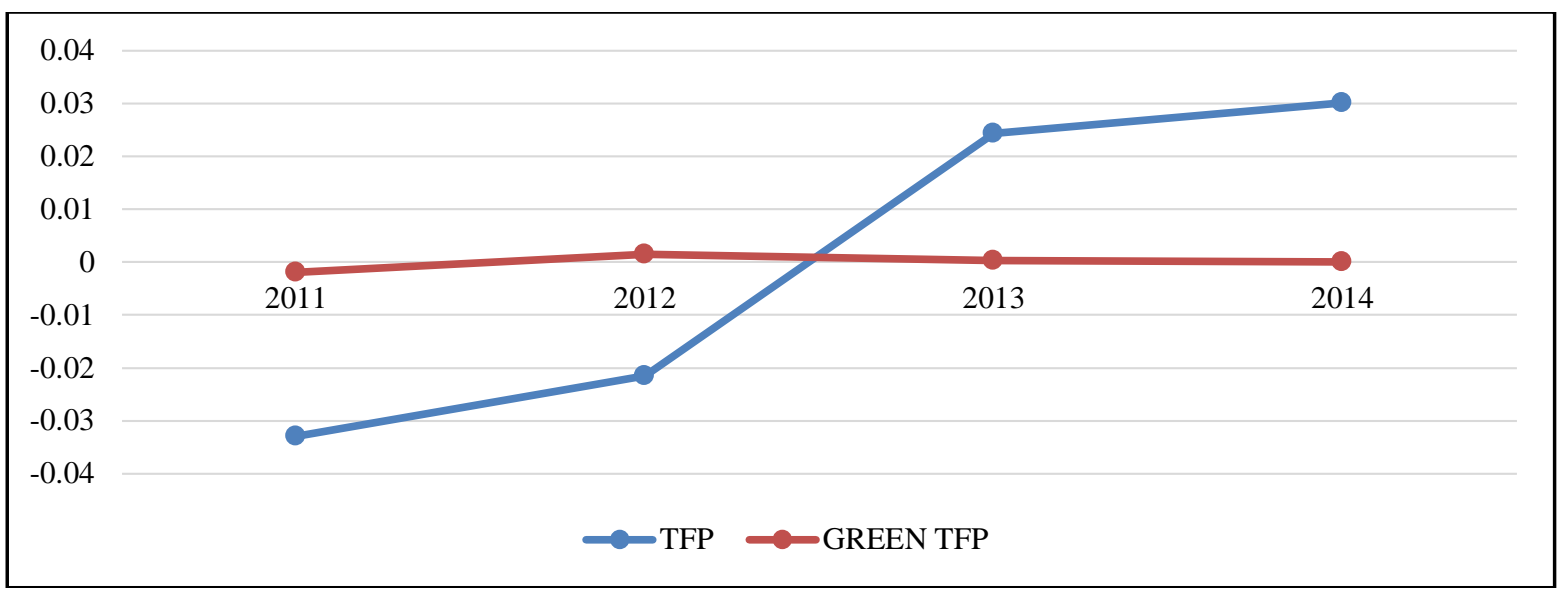

Gambar 10. Perkembangan Total Factor Productivity dan Green Total Factor Productivity Indonesia 2011-2014

Terlihat bahwa selama periode penelitian (2011-2014), rata-rata pertumbuhan Total Factor Productivity di Indonesia mengalami peningkatan yang cukup signifikan terutama pada tahun 2013. Pada tahun 2011 dan 2012 TFP di Indonesia sebesar -0,03 dan -0,02 sedangkan pada tahun 2013 dan 2014 mengalami peningkatan menjadi 0,02 dan 0,03. Hal ini menunjukkan bahwa Indonesia secara rata-rata lebih efisien dalam menggunakan input pertumbuhan ekonominya yaitu modal dan tenaga kerja dalam meningkatkan pertumbuhan ekonomi di Indonesia.

\section{G. Pemetaan Provinsi di Indonesia menurut Tingkat Total Factor Productivity}

Pembangunan ekonomi merupakan kegiatan yang perlu memperhatikan karakteristik masing-masing daerah atau provinsi di Indonesia. Perbedaan karaktersitik provinsi mengindikasikan perlakuan yang berbeda untuk mendapatkan peningkatan produktivitas yang optimal dalam tujuan pembangunan setiap provinsi. Gambar 18 menyajikan peta provinsi di Indonesia berdasarkan tingkat TFP yang dimiliki pada tahun 2014. Provinsi baik yang tingkat TFP nya relatif rendah, sedang, atau tinggi terlihat sedikit acak atau tidak memiliki pola spasial. Namun, apabila kita perhatikan untuk provinsi yang kategori sedang dan tinggi di dominasi oleh provinsi besar di Indonesia seperti DKI Jakarta, Sumatera Utara, dan Kalimantan Selatan. Untuk Pulau Jawa dan Bali sendiri, tidak ada satupun provinsi yang memiliki tingkat TFP relatif rendah. Hal ini memang sangat wajar mengingat Pulau Jawa merupakan pusat perekonomian di Indonesia.

Di setiap pulau di Indonesia memiliki provinsi tingkat TFP relatif Tinggi seperti Sumatera Utara di Pulau Sumatera, DKI Jakarta dan Jawa Timur di Pulau Jawa, Kalimantan Selatan di Pulau Kalimantan, Sulawesi Utara dan Gorontalo di Pulau Sulawesi serta Maluku dan Maluku Utara. Setiap provinsi yang tingkat TFP relatinf tinggi dapat dijadikan sebagai referensi pembelajaran kegiatan peningkatan produktivitas, terutama bagi provinsi yang masih memiliki tingkat TFP relatif rendah. Provinsi-provinsi ini dapat dijadikan sebagai pusat pengembangan tingkat TFP di setiap Pulau di Indonesia sehingga tidak harus menjadikan DKI Jakarta sebagai referensi mengingat provinsi yang lebih berdekatan memiliki karakteristik yang hampir sama. Namun, untuk Pulau Papua sendiri, belum ada provinsi yang memiliki tingkat TFP relatif tinggi. Ini menjadi tugas untuk pemerintah setempat untuk meningkatkan produktivitas mereka dalam mengelola sumber daya yang dimiliki.

\section{KESIMPULAN}

Berdasarkan hasil dan pembahasan dari penelitian yang dilakukan, maka diperolehkesimpulan sebagai berikut: 
1. Tingat investasi dan angakatan kerja berpengaruh positif dan signifikan terhadap pertumbuhan ekonomi Indonesai. Faktor yang memiliki tingkat elastis paling tinggi dalam pertumbuhan ekonomi adalah variabel tenaga kerja.

2. Total Factor Productivity Indonesia selalu mengalami peningkatan setiap tahunnya namun sebaliknya Green Total Factor Productivity mengalami penurunan mulai tahun 2012 setiap tahunnya, sehingga Total Factor Productivity sudah tidak lagi relevan dijadikan alat pengambil kebijakan karena kondisi produktivitas yang dihasilkan semu karena jauh berbeda apabila kita membandingkan dengan Green Total Factor Productivity.

\section{DAFTAR PUSTAKA}

Agung, I.G.N., N.H.A. Pasay, dan Sugiharso. (2008). Teori Ekonomi Mikro: Suatu Analisis Produksi Terapan. Jakarta:PT RajaGrafindo Persada.

Boediono. (1999). Teori Pertumbuhan Ekonomi.Yogyakarta: BPFE-UGM.

Boediono. (1992). Teori Pertumbuhan Ekonomi, Seri Sinopsis Pengantar Ilmu Ekonomi (Edisi 1). Yogyakarta:BPFE-UGM.

Comin, Diego. (2006). Total Factor Productivity. NBER August 2006, Working paper (25-072012)

Greene, W.H. (2000). Econometric Analysis(3rd ed). New Jersey:Prentice Hall.

Gujarati, Damodar N. dan Dawn C. Porter. (2003). Basic Econometrics(5 ${ }^{\text {th }}$ ed). New York: McGraw Hill International Edition.

Johnson, Richard A. dan Wichern, Dean W. (2002). Applied MultivariateStatistical Analysis. Fifth Edition. New Jersey : Prentice-Hall, Inc.

Miller, Rogeer LR, Meiners. (2000). Teori Ekonomi Intermediate ( $3^{\text {rd }}$ ed). Jakarta :Raja Grafindo Persada.

Mubyarto. (1986). Pengantar Ekonomi Pertanian. Jakarta: LP3ES.

Salvatore, Dominick. (2006). Mikroekonomi Edisi Empat. New York:McGraw-Hill, Inc.

Simanjuntak, Payaman J. (2005). Pengantar Ekonomi Sumber Daya Manusia. Jakarta:FE-UI

Soeharno. (2007). Teori Mikroekonomi. Yogyakarta:Andi Offset.

Soekartawi. (2001). Pengantar Agroindustri. Jakarta:PT Raja Grafindo Persada.

Solow, Robert.M. (1956). A Contribution to The Theory of Economic Growth. Quarterly Journal of Economics (64-94).

Solow, Robert.M. (1957). Technical Change and The Agregat Production Function. Mashachusets:MIT Press Table.

Sudarsono. (1998). Ekonomi Sumber Daya Manusia. Jakarta:Universitas Terbuka.

Sukirno, Sadono. (1994). Pengantar Teori Ekonomi Makro. Edisi Pertama. Jakarta: PT Raja Grafino Perkasa.

Sukirno, Sadono. 2000. Ekonomi Pembangunan Proses, Masalah dan Dasar Kebijakan Pembangunan. UI-Press. Jakarta.

Sukirno, Sadono. (2005). Teori Pengantar Mikro Ekonomi (Edisi Ketiga). Jakarta:Raja Grafindo Persada.

Todaro, Michael P., \& Stephen C. Smith. (2009). Pembangunan Ekonomi di Dunia Ketiga. Edisi Kedelapan. (Haris Munandar, \& Puji A.L., Trans.). Jakarta: Erlangga

W.A. Brock. (1973). A Polluted Golden Age, in "Economics of Natural and Environmental Resources" (V.L. Smith, Ed.). New York: Gordon \& Breach

Xepapadeas,A. (2005). Economic Growth and the Environment in the "Hand-book of Environmental Economics", Economy wide and InternationalEnvironmental Issues. University of Crete:Elsevier Publishers 